\title{
On Guarantees of Realisation of Personal Inviolability Principle at Detention of Suspect
}

\author{
Alimkulov Erbol Temirkhanovich \\ PhD (Law), Associate Professor of the Department of Criminal Law, Criminal Procedure and Criminalistics, \\ Al-Farabi Kazakh National University, Kazakhstan, Almaty; Corresponding author's mail: alerbol@mail.ru
}

\section{Bayandina Mainur Okanovna}

Senior Lecturer of the Department of Criminal Law, Criminal Procedure and Criminalistics Al-Farabi Kazakh National University Kazakhstan, Almaty

\section{Bersugurova Lyaziza Shaltaevna}

Full Doctor of Law, Professor of the Department of Criminal Law, Criminal Procedure and Criminalistics Al-Farabi Kazakh National University Kazakhstan, Almaty

\section{Zhanibekov Akynkozha Kalenovich}

PhD, Associate Professor of the Department of Criminal Law, Criminal Procedure and Criminalistics Al-Farabi Kazakh National University Kazakhstan, Almaty

\section{Mukhamadieva Gul'zhan Nusupzhanovna}

Associate Professor of the Department of Criminal Law, Criminal Procedure and Criminalistics Al-Farabi Kazakh National University Kazakhstan, Almaty

\section{Doi:10.5901/mjss.2015.v6n6p273}

\section{Abstract}

This article deals with the nature of personal inviolability principle as a fundamental and principle source of Kazakhstan criminal proceeding. The author actualizes a need for further development of legislation defining legal framework of the personal inviolability in criminal proceeding. The article presents legal analysis of guarantees of personal inviolability realisation at the detention of a suspect.

Keywords: personal inviolability principle, criminal proceeding, guarantees, detention of suspect, measures of compulsion.

\section{Introduction}

Personality status is a principle category serving as basis for inviolability of a person. Legal status of a person is predetermined primarily by political and legal structure of the state, which is established in its constitutional law. At present we usually regard the legal status from the point of view of person's democratic rights, freedoms and lawful interests. Inviolability of person as a right was actualised only in modern Kazakhstan society - when citizens voted for the current Constitution in 1995 and chose democratic way of development. One of the first chapters of the Constitution is dedicated to the rights and freedoms of citizens, establishing priorities for the whole governmental structure.

The law should clearly outline the limits behind which a person is "vulnerable" or "attainable" to the state using a system of measures of compulsion. Freedom of person does not exist beyond these limits, and in the event of violation of these limits the infringer has legal responsibility.

This said, we should also mention that the limits as well as responsibility as a response measure are established from the point of view of legal equality. This criterion defines the essence of a constitutional state where the law is a universal and just standard for living of society. An example of it is one of provisions of the Constitution, stating: "Everyone shall be equal before the law and court" (p. 1 Art. 14) [The Constitution of the Republic of Kazakhstan, 1996]. If a person has a constitutional right for inviolability of person, then the state shall be obliged to guarantee its realisation for 
every individual. This provision has crucial meaning when a person is under a criminal and legal pressure. This is the reason for rendering the right for inviolability of person a new quality - quality of a predetermining and basic principle of criminal proceeding.

The category of inviolability of person as a principle of criminal proceeding comprises each stage of proceeding and has utmost importance when the measures of criminal procedure compulsion are applied. At present the problem of inviolability of person has clear prospects of legal settlement. This is primarily associated with democratic revisions of the whole state - legal system of the republic.

\section{Personal Inviolability Principle at Detention of Suspect}

Principle of inviolability of person is specified in Art. 14 of CrPC RK [Criminal Procedure Code of the Republic of Kazakhstan, 2014]. It presents independent crucial meaning for criminal procedure science.

Procedural order of personal restraint under criminal proceeding is the basis for principle of inviolability of person. It is realised through measures of criminal procedure compulsion: detainment, custodial detention; involuntary placement of the person who is not imprisoned into a medical organization to carry out medico-legal psychiatric assessment or forensic medical examination; indemnification of damage caused to a citizen as a result of illegitimate restraint of liberty, having been kept in conditions dangerous to his life and health, or his cruel treatment.

Detainment is one of the basic measures of personal restraint of a citizen in criminal proceeding. Its main objective is to establish person's implication in a crime he/she is suspected of. Detainment is an integral part of procedural compulsion institute together with other types of procedural compulsion - measures of restraint (recognizance not to leave and behave properly; personal surety; submission of a military serviceman under the supervision of the command of the military unit; submission of a juvenile under supervision; pledge; house arrest; arrest), as well as other measures of procedural compulsion (commitment to appear, compulsion to appear, temporal discharge from office, imposition of arrest on property, barring order) [The Constitution of the Republic of Kazakhstan, 1996]. In its turn, detention consists of a separate system of criminal procedure provisions.

Authorisation of criminal authorities for detention is a sort of embodiment of system of State agencies having coercive powers and compulsory force within system of official enforcement. Procedural detention is a first measure of procedural compulsion. From this moment a person suspect in the crime is practically "under the jurisdiction" of criminal authorities and has a status of a suspect, whose rights and freedoms are limited by provisions of procedural law. Among them the right for inviolability of person is fundamental: it guarantees inviolability of the person's freedoms and lawful interests. Effectively, procedural detention deprives the person of one of main rights - the right to personal liberty. Therefore, we can say that detention is a type of deprivation of liberty prescribed by the law. According to the provisions of the law, period of procedural detention is limited to 72 hours, so detention is a short-term deprivation of liberty, limiting a person in independent activities and arrangement of himself and his time. Detention limits the following:

1) individual freedom to arrange him/herself at sole option;

2) physical, moral and mental inviolability of person.

This measure is qualified as urgent investigative act (Art.196 of CrPC). From the point of view of criminalists, procedural detention of a suspect is one of the most important tactical operations, performed at a stage of establishment of person who committed general crime, if not obvious [Obraztsova, 1999].

In a democratic state personal restraint in form of detention is admissible in all abovementioned cases on the basis of the law and judicial decision. The best guarantee of realisation of personal inviolability principle is a mandatory requirement for compliance with the law at the detention. Provisions of international, constitutional, administrative, criminal and procedural law regulate guarantees against illegal personal restraint. Thus, the Convention for the Protection of Human Rights and Fundamental Freedoms (Rome, November 4, 1950) stipulates legitimate grounds for detention of a person. Among them are:

a) the lawful detention of a person after conviction by a competent court;

b) the lawful arrest or detention of a person for non-compliance with the lawful order of a court or in order to secure the fulfilment of any obligation prescribed by law;

c) the lawful arrest or detention of a person effected for the purpose of bringing him before the competent legal authority on reasonable suspicion of having committed an offence or when it is reasonably considered necessary to prevent his committing an offence or fleeing after having done so;

d) the detention of a minor by lawful order for the purpose of educational supervision or his lawful detention for the purpose of bringing him before the competent legal authority;

e) the lawful detention of persons for the prevention of the spreading of infectious diseases, of persons of 
unsound mind, alcoholics or drug addicts or vagrants;

f) the lawful arrest or detention of a person to prevent his effecting an unauthorised entry into the country or of a person against whom action is being taken with a view to deportation or extradition [Convention on the Protection of Human Rights and Fundamental Freedoms, 2000].

The Constitution of RK stipulates: "Arrest and detention shall be allowed only in cases stipulated by law and with the sanction of a court with right of appeal of an arrested person" (p.2 Art. 16) [The Constitution of the Republic of Kazakhstan, 1996].

According to the Criminal Procedure Code of the RK, the detention of a suspect in the crime is performed in order to terminate crime and solve the question of putting him under restraint or to provide proceedings as to the crime where it is reasonable to presume that the person can escape or commit a more serious crime (p.1 Art. 128 of CrPC RK).

Supplementary guarantee of legal detention of suspects is provided by the fact that detention can only be made by an authorised authority. According to the CrPC RK it is a criminal authority.

Together with an authorised authority, the victims and other citizens also have the right to make detention. According to the Art. $130 \mathrm{CrPC}$ RK, it is acceptable only in order to restraint the opportunity of commission of other offenses by that person. A person making a detention have the right, with observance of the rules provided for by Article 233 of the CrPC, to immediately perform a bodily search of a detainee in cases when there are reasons to believe that he has weapon or objects that can be used as weapon, or prohibited items, or other items that can be used for averment, or if tries to hide evidences which prove that he committed a crime or in other similar cases (Art. 135 of CrPC RK). Seized dangerous objects, in particular arms, shall mandatory be transferred to law-enforcement authority or any other authority.

One of the most important guarantees of inviolability of person principle at the procedural detention is participation of a defence attorney. A right of a suspect to defense corresponds to obligation of criminal authorities to provide the defence attorney. Fulfilment of this obligation largely promotes realisation of inviolability of person at a pre-litigation stage of proceeding. Regulatory Resolution of the Supreme Court of the Republic of Kazakhstan of December 6, 2002 No. 26 "On Practical Application of Criminal Procedure Legislation Regulating the Right to Defense" states that "ensuring the right of a suspect to defense by the bodies with carriage of the criminal process together with other principles of criminal proceedings guarantee fair trial and correct decision of the case [Normative Resolution of the Supreme Court of the Republic of Kazakhstan, 2010]. Thus, infringement of the right to defense can entail consequences prescribed by the Art. 9 of $\mathrm{CrPC}$ RK, according to which "... violation, depending on its nature and importance, shall entail invalidity of the conducted proceedings on a case, a reversal of the decisions made during such proceedings or a declaration that the collected materials shall not be admitted as evidences" [Criminal Procedure Code of the Republic of Kazakhstan, 2014].

Advocate shall participate as a counsel for the defence. Under participation of an advocate in the criminal procedure as a counsel for the defence, besides him, the defence of the convict, the accused, the person on trial, the suspect, the legally warranted person may be performed by his or her spouse or an immediate relative or a guardian, trustee or representative of the organization under which custody and dependence the suspect, the accused, the person on trial, the convict, the acquitted person are in. This is a very important part of the guarantee of right to defense.

According to the Art. 70 of $\mathrm{CrPC}$, the counsel for the defence shall be allowed to participate in a case from the time of detention of criminal suspect or from the moment of administration of measure of restraint in form of pre-trial detention, as well as from the moment of presentation of denunciations or regulation on administration of this measure, but not later than 24 hours after detention.

The right to defense allows a suspect (accused) to individually or with the help of a counsel for the defence maintain innocence or provide mitigating circumstances. But the right of suspect (accused) to defense not only provides protection of his lawful interests, but also facilitates successful solution of tasks of justice, including correct conduction of preliminary inquiry. In this regard a principle, regulating the right to defense is a crucial component of inviolability of person. With a possibility to defence individually as well as with the help of a professional lawyer, a person under criminal proceeding has guarantee for protection of his rights and lawful interests.

Participation of a counsel for the defence at a preliminary inquiry rises its level of objectiveness, allows to evaluate all incriminated counts more thoroughly, and in some cases even arrive at a decision of innocence. Main objective of a counsel for the defence participating at a preliminary inquiry is to establish facts of observation of procedural rules and to find facts justifying or alleviating guilt of his client.

Quick review of provisions of current CrPC shows significant reformations in the legislation of the republic. However, regardless new democratic basis of defence in proceeding and improved position of citizens' rights and lawful interests, problem of practical realisation of right for professional legal help and defence of proceeding participants still persists. Rights and freedoms of participants can still be subject to involuntary restriction on a common basis.

A counsel for the defence should employ all legal means to find facts justifying a suspect (accused) or mitigating 
his liability, as well as to lend necessary legal assistance. From the moment of admission to the case, a counsel for the defence has a complex of rights which basically are the warrants of his protective activity. To the category of such rights and guarantees we subsume the right to have meetings with the suspect or the accused in private and in confidence without restrictions of their number and length. In addition, a counsel for the defence has the right to collect and present items, documents and information which are required for rendering aid and advice in legal matters; be present when accusal is presented, participate in the interrogation of the suspect and (or) the accused, as well as in other investigative and legal proceedings, which are performed with their participation or in compliance with their petition or the petition of the counsel for the defence himself; file the recusal; become familiar with the detention report, resolution on application of a measure of restraint, with the records of investigative acts performed with the participation of the suspect, the accused or the counsel for the defence himself, with the documents which have been presented or shall have been presented to the suspect and (or) the accused, and in the end of interrogation, summary pre-trial procedure or preliminary investigation - with all materials of the case; copy out any information from it in any volume; file petitions; participate in preliminary hearings of the case, in judicial proceedings at the court of any instance; speak in judicial pleadings, participate in sessions of the court when a case is resumed due to newly discovered circumstances; become familiar with a record of a judicial session; receive copies of procedural documents; protest against unlawful acts of the person who conducts the criminal procedure and other persons who participate in the criminal proceeding; require inclusion of those objections into procedural documents; file complaints with regard to acts and decisions of the interrogating officer, investigator, prosecutor and court; and participate in their consideration; use any other means and methods of defence which do not contradict the law [Criminal Procedure Code of the Republic of Kazakhstan, 2014].

An advocate participating as a counsel for the defence also has a right to: petition to the court on deposit of witness's and victim's evidence; petition to the investigating judge on discovery of information, documents, objects necessary for professional legal assistance and protection of the interests of a suspect, accused, witness having a right to defense (excluding information presenting state secrets) in case the demand is dismissed or ignored for more than 3 days; petition to the investigating judge on commissioning of expert evidence, if criminal authority unreasonably dismissed such petition or did not decide during 3 days; interview (including with the help of technical means) persons who know something as to the facts of the case, and to petition on inclusion of received data; receive expert evidence on a negotiable basis and petition on their inclusion; petition to the investigating judge on reconduction of earlier interviewed witness to the criminal authority in case his procurement is troubled.

A counsel for the defence participating in case proceeding has a right with the permission of the investigator (or interrogating officer) to ask questions to the interviewed persons. An investigator (or interrogating officer) can disallow a question of a counsel for the defence, but is obliged to place all the questions in the minutes. A counsel for the defence can make written comments in the minutes as to its correctness and completness.

The counsel for the defence shall not: to commit any acts against the interests of the accused and to impede the exercise of the rights belonging to him; contrary to the position of the accused to recognise his implication in a crime and culpability of its commission, to declare reconciliation of the accused with the victim; to recognise a civil lawsuit; to revoke complaints and petitions filed by the accused; to disclose information which became known to him in connection with the application for his legal assistance and its exercise [Criminal Procedure Code of the Republic of Kazakhstan, 2014, Art. 74].

The Art. 27 of CrPC RK guarantees professional defence by lawyers. Legal status of a lawyer is regulated by the Law of RK "On Advocate Practice", according to which the organization and operation of advocacy is based on the principles of independence and legality [Law of the Republic of Kazakhstan, 1997]. Though, at practice, as it was mentioned before, lawyers not always are able to equally stand against powerful state agencies as the court and investigation from the point of view of equality and adversariality principles. Professional counsel for the defence is obliged to work against all the efforts of coercion upon his independence. He in no way must compromise requirements of professional duty and ethics. This is stipulated not only by professional duty, but also by current advocate legislation. Elimination of outside influence upon activity of a counsel for the defence is a general rule, prohibiting interference of state authorities, public organisations and officials. This rule is stipulated by provisions of virtually all legal acts of former republics of the USSR, regulating advocate practice in criminal proceeding [Zhalybin, 1998].

Danger to the interests of a person and his inviolability stems from violation of equal and adversary proceedings and from mitigating of counsel for the defence 's role, as a counsel for the defence (let alone a professional one) present the procedural guarantee of realisation of rights and freedoms of a person under criminal proceeding. Thus, every time the violation of principle of personal inviolability takes place, we find that the role of counsel for the defence, his rights and responsibilities are somehow limited (for example, the procuratorate, court, agency of inquiry and preliminary inquiry, other state agencies, officials and organisations interfere with activity of a counsel for the defence. 


\section{Conclusion}

Therefore, speaking about personal inviolability we enter the sphere of influence of governmental and legal mechnism applying methods of official enforcement, among which special place is occupied by measures of criminal procedure compulsion. Under criminal proceeding freedom of a person is restricted because of his status of a suspect or an accused of committing the most dangerous kind of infraction - crime, so in connection with it measures of criminal procedure compulsion are applied to him. Measures of compulsion restricting the freedom are necessary under a criminal proceeding. They are used in order to investigate a crime, and to provide legal order of an accused (a suspect) permitting the investigation to comprehensively and fairly conduct a case to solve a crime. Legal measures of procedural compulsion restricting freedom and other rights are socially justified. The state takes on responsibilities for public order, so with the help of legal instruments it establishes a system, machinery and framework (we here refer to the sphere of criminal proceeding) for application and realisation of official enforcement. Enforcement in criminal, criminal procedural and penal spheres will always be present in all the regimes. The question obviously abuts on realisation of democratic postulates, which make the interests of a person the cornerstone. So at present we should be mostly worried about following:

- if the freedoms of person and his democratic rights will be securely protected and inviolable under the measures of procedural compulsion;

- which legal instruments are used by the law-maker;

- if legal provisions are realised in the law enforcement practice etc.

The following aspect becomes the fundamental one in this regard. Democratic status of a person requires legislative support and necessary limits, which guarantee personal freedom even in the sphere of criminal procedure where it is coercively restricted. These "limits" are defined by legal and particularly constitutional guarantees of realisation of personal rights and freedoms. Provisions of criminal law specify the guarantees in regard to specific character of criminal proceeding and measures of procedural compulsion.

\section{References}

Convention on the Protection of Human Rights and Fundamental Freedoms (Rome, 4 November 1950) International human rights instruments. Collection of documents. - Moscow: NORMA Group - INFRA. M, 2000. 784 p.

Criminal Procedure Code of the Republic of Kazakhstan dated July 4, 2014 № 231, Kazakhstan truth, №. 133 (27754);

Law of the Republic of Kazakhstan dated December 5, 1997 N 195-1 "On Advocacy", Bulletin of the Parliament of the Republic of Kazakhstan, 1997, N 22, art. 328

Normative Resolution of the Supreme Court of the Republic of Kazakhstan dated December 6, $2002 \mathrm{~N} 26$ On the practice of criminal procedure legislation regulating the right to protection, Bull. AF RK. 2010. No. 8.

Obraztsova V.A. Forensic science: the textbook. -2nd Edition, Moscow: Jurist, 1999. 735 p.

The Constitution of the Republic of Kazakhstan (adopted at the national referendum on 30 August 1995), Bulletin of the Parliament of the Republic of Kazakhstan, 1996, N 4, p. 217;

Zhalybin S.M. The legal status of a lawyer in criminal proceedings. Almaty: Zheti Zhargy, 1998. 128 p. 